\title{
Metabolic regulation of Escherichia coli and its phoB and phoR genes knockout mutants under phosphate and nitrogen limitations as well as at acidic condition
}

\author{
Lolo Wal Marzan ${ }^{1}$ and Kazuyuki Shimizu ${ }^{1,2^{*}}$
}

\begin{abstract}
Background: The phosphorus compounds serve as major building blocks of many biomolecules, and have important roles in signal transduction. The phosphate is involved in many biochemical reactions by the transfer of phosphoryl groups. All living cells sophisticatedly regulate the phosphate uptake, and survive even under phosphate-limiting condition, and thus phosphate metabolism is closely related to the diverse metabolism including energy and central carbon metabolism. In particular, phosphorylation may play important roles in the metabolic regulation at acidic condition and nitrogen limiting condition, which typically appears at the late growth phase in the batch culture. Moreover, phosphate starvation is a relatively inexpensive means of gene induction in practice, and the phoA promoter has been used for overexpression of heterologous genes. A better understanding of phosphate regulation would allow for optimization of such processes.
\end{abstract}

Results: The effect of phosphate (P) concentration on the metabolism in Escherichia coli was investigated in terms of fermentation characteristics and gene transcript levels for the aerobic continuous culture at the dilution rate of $0.2 \mathrm{~h}^{-}$

${ }^{1}$. The result indicates that the specific glucose consumption rate and the specific acetate production rate significantly increased, while the cell concentration decreased at low P concentration (10\% of the M9 medium). The increase in the specific glucose uptake rate may be due to ATP demand caused by limited ATP production under Plimitation. The lower cell concentration was also caused by less ATP production. The less ATP production by H ${ }^{+}$-ATPase may have caused less cytochrome reaction affecting in quinone pool, and caused up-regulation of ArcA/B, which repressed TCA cycle genes and caused more acetate production. In the case of phoB mutant (and also phoR mutant), the fermentation characteristics were less affected by P-limitation as compared to the wild type where the PhoB regulated genes were down-regulated, while phoR and phoU changed little. The phoR gene knockout caused phoB gene to be down-regulated as well as PhoB regulated genes, while pho $U$ and phoM changed little. The effect of $\mathrm{pH}$ together with lower $\mathrm{P}$ concentration on the metabolic regulation was also investigated. In accordance with up-regulation of arcA gene expression, the expressions of the TCA cycle genes such as sdhC and $m d h$ were downregulated at acidic condition. The gene expression of rpoS was up-regulated, and the expression of gadA was upregulated at $\mathrm{pH}$ 6.0. In accordance with this, PhoB regulated genes were up-regulated in the wild type under P-rich and P-limited conditions at $\mathrm{pH} 6.0$ as compared to those at $\mathrm{pH}$ 7.0. Moreover, the effect of nitrogen limitation on the metabolic regulation was investigated, where the result indicates that $p h o B$ gene was up-regulated, and PhoB regulated genes were also up-regulated under N-limitation, as well as nitrogen-regulated genes.

Conclusion: The present result shows the complicated nature of the metabolic regulation for the fermentation characteristics upon phosphate limitation, acidic condition, and nitrogen limitation based on the transcript levels of selected genes. The result implies that the regulations under phosphate limitation, acidic condition, and nitrogen

\footnotetext{
* Correspondence: shimi@bio.kyutech.ac.jp

'Department of Bioscience \& Bioinformatics, Kyushu Institute of Technology,

lizuka, Fukuoka 820-8502, Japan

Full list of author information is available at the end of the article
} 
limitation, which occur typically at the late growth phase of the batch culture, are interconnected through RpoS and RpoD together with Pho genes.

Keywords: phoB gene knockout, phoR gene knockout, phosphate limitation, pH, nitrogen limitation

\section{Background}

The phosphorus compounds serve as major building blocks of many biomolecules, and have important roles in signal transduction [1]. The phosphate is contained in lipids, nucleic acids, proteins, and sugars, and is involved in many biochemical reactions by the transfer of phosphoryl groups [2]. Moreover, phosphate metabolism is closely related to the diverse metabolisms such as energy and central carbon metabolisms [3]. All living cells sophisticatedly regulate the phosphate uptake, and survive even under phosphate-limiting condition $[4,5]$. Escherichia coli contains about $15 \mathrm{mg}$ of phosphate (P) per g (dry cell weight) [6]. Depending on the concentration of environmental phosphate, E. coli controls phosphate metabolism through Pho regulon, which forms a global regulatory circuit involved in a bacterial phosphate management $[1,7]$. The PhoR-PhoB two-component system plays an important role in detecting and responding to the changes of the environmental phosphate concentration [8-10]. It has been known that PhoR is an innermembrane histidine kinase sensor protein that appears to respond to variations in periplasmic orthophosphate $\left(\mathrm{P}_{\mathrm{i}}\right)$ concentration through interaction with a phosphate transport system, and that $\mathrm{PhoB}$ is a response regulator that acts as a DNA-binding protein to activate or inhibit specific gene transcription [1,11-13]. The activation signal, a phosphate concentration below $4 \mu \mathrm{M}$, is transmitted by a phospho-relay from PhoR to PhoB. PhosphoPhoB in turn controls Pho regulon gene expressions. PhoB is phosphorylated by PhoR under phosphate starvation or by PhoM (or $\mathrm{CreC}$ ) in the absence of functional PhoR [14-20].

The E. coli Pho regulon includes 31 (or more) genes arranged in eight separate operons such as eda, phnCDEFGHIJKLMNOP, phoA, phoBR, phoE, phoH, psiE, pstSCAB-phoU, and ugpBAECQ [21]. When $\mathrm{P}_{\mathrm{i}}$ is in excess, PhoR, Pst, and PhoU together turn off the Pho regulon, presumably by dephosphorylating PhoB. In addition, two $\mathrm{P}_{\mathrm{i}}$-independent controls that may be form of cross regulation turn on the Pho regulon in the absence of PhoR. The sensor $\mathrm{CreC}$, formerly called PhoM, phosphorylates PhoB in response to some (unknown) catabolite, while acetyl phosphate may directly phosphorylate PhoB [7]. When $\mathrm{P}_{\mathrm{i}}$ is in excess, $\mathrm{P}_{\mathrm{i}}$ is taken up by the low affinity $\mathrm{P}_{\mathrm{i}}$ transporter, Pit. Four proteins such as PstS, PstC, PstA and PstB form an $\mathrm{ABC}$ transporter important for the high-affinity capture of periplasmic inorganic phosphate $\left(P_{i}\right)$ and its low- velocity transport into the cytosol [22]. These proteins are encoded together with PhoU as the pstSCAB-phoU operon. PstS is a periplasmic protein that binds $P_{i}$ with high affinity. PstC and PstA are innermembrane channel proteins for $P_{i}$ entry, while PstB is an ATP-dependent permease that provides the energy necessary for $P_{i}$ transport from periplasm to cytosol. When phosphate is in excess, the Pst system forms a repression complex with PhoR, and prevents activation of PhoB. PhoU and PstB are also required for dephosphorylation of phospho-PhoB under P-rich condition [23]. Indeed, PhoU is essential for the repression of the Pho regulon under high phosphate condition [1]. It may be considered that PhoU acts by binding to PhoR, PhoB or PhoR/PhoB complex to promote dephosphorylation of phosphorylated PhoB or by inhibiting formation of the PhoR-PhoB complex [24].

It has been shown that $p h o B$ mutant does not synthesize alkaline phosphatase ( $p h o A$ gene product) [25-30] and phosphate binding protein ( $p s t S$ gene product) $[26,29,30]$. It was observed that phoU expression changed depending on phosphate concentration of the phoB mutant [31]. Since the phoA gene mutation leads to the decreased content of membrane proteins or completely lacks them, mutations in the $p h o B$ gene result in the loss of alkaline phosphate and two membrane proteins [32]. Nesmeianova et al. [25] found that phoB mutation leads to loss of polyphosphate kinase activity which catalyzes the synthesis of polyP in E. coli. Ault-Riché et al. [33] also found that the strains with deletion of $p h o B$ failed to accumulate polyP in response to osmotic stress or nitrogen limitation. Mutations in the $p h o B$ gene had no effect on pepN [34] and lky (tolB) expressions [35].

The expressions of the genes under the control of the PhoR-PhoB two-component system were found to be affected by the duration of $\mathrm{P}$-limitation in response to phosphate starvation in E. coli. This means that the roles of the PhoR-PhoB two-component regulatory system seem to be more complex [10]. Although molecular level regulation by PhoR-PhoB under P-limitation has been investigated as stated above, little has been investigated about the effect of P- limitation on the overall metabolism and fermentation characteristics of $E$. coli so far. In the present study, therefore, we investigated the effect of phosphate limitation on the cell metabolism in E. coli in view of fermentation characteristics and gene transcript levels, since it is quite important for the development of microbial cell factories to understand the fermentation 
mechanism at the late growth phase in the batch culture, where nutrient starvation occurs. Moreover, the effect of phoB gene (and also phoR gene) knockout on the metabolism was also investigated under both P-rich and $\mathrm{P}$-limited conditions to clarify the role of phosphate regulation. Since it has been implied that phosphate regulation is interconnected with acid tolerance and nitrogen regulation, we also investigated the effect of $\mathrm{pH}$ downshift and nitrogen limitation together with P-limitation on the metabolic regulation in E. coli, where those phenomena also occur at the late growth phase of the batch culture. Since phosphate starvation is a relatively inexpensive means of gene induction in practice, the $p h o A$ promoter has been used for overexpression of heterologous genes [36]. A better understanding of the Pho regulon would allow for optimization of such processes [22].

\section{Results}

\section{Effect of phosphate limitation on the metabolism}

In order to make clear the effect of phosphate limitation on the metabolism, aerobic continuous cultivation was conducted at the dilution rate of $0.2 \mathrm{~h}^{-1}$ under different $\mathrm{P}$ concentrations. Additional file 1a shows the effect of $\mathrm{P}$ concentration on the fermentation characteristics of the wild type strain, where it indicates that the fermentation characteristics significantly changed when feed P concentration became low around 10\% of the M9 medium. In particular, the specific glucose consumption rate and the specific acetate production rate became significantly higher, while cell concentration became significantly lower under such P-limiting condition. Table 1a also shows the detailed values.

Figure 1 shows the effect of $\mathrm{P}$ concentration on the transcript levels, where Figure $1 \mathrm{~b}$ indicates that $p h o B$ transcript level increased as $\mathrm{P}$ concentration decreases, and phoB regulated genes such as $p h o A$, phoE, phoH, phnC, $p s t S$, and $u g p B$ were all increased in a similar fashion, and eda transcript level also changed in a similar fashion (Figure 1c). Note that phoU and phoM changed in a similar fashion as $p h o R$, and also that the transcript level of rpoD, which encodes the RNA polymerase holoenzyme containing $\sigma^{70}$, increased in a similar fashion as $\mathrm{PhoB}$ regulatory genes [37]. Figure 1a also indicates that the transcript level of $\operatorname{arcA}$ increased as $\mathrm{P}$ concentration decreases, and those of $s d h C$ and $m d h$ genes decreased (Figure 1c and Additional file 2). Figure 1 also shows that cra transcript level decreased, and thus the transcript levels of $p t s H$ and $p y k F$ increased (Additional file 2). Those are consistent with the increased specific glucose consumption rate (Table 1 and Additional file 1a). The decrease in cra transcript level may be due to higher glucose concentration. The transcript level of $f n r$ is somewhat different from $\operatorname{arcA}$ but that of $y f i D$ changed in a similar fashion as fnr (Additional file 2). Moreover, Figure 1a also indicates that sox $R / S$ transcript levels increased as $P$ concentration decreases, and accordingly the transcript levels of $r p o D, z w f$ and $\operatorname{sod} A$ changed in a similar fashion (Additional file 2). The respiratory chain genes such as atpA, ndh, and nuoA also changed in a similar fashion, implying that the respiration is activated under P-limitation. Figure $1 \mathrm{~d}$ shows that rpoN which encode $\sigma^{54}$ increases as $\mathrm{P}$ concentration decreased.

Table 1 also shows the effect of $p h o B$ gene knockout on the fermentation characteristics under both P-rich and lower P conditions, where it indicates that the glucose concentration increased and cell concentration decreased for the $p h o B$ mutant as compared to the wild type, and that the specific acetate production rate was higher at $\mathrm{P}$ rich condition and $55 \%$ of $\mathrm{P}$ concentration for the $p h o B$ mutant as compared to the wild type. It is surprising that the fermentation characteristics were less affected even under P-limitation (10\% and 5\%) for the phoB mutant, whereas the wild type shows significant changes at $10 \%$ of $\mathrm{P}$ concentration. In the case of phoB mutant, cell could survive even at $1 \%$ of $\mathrm{P}$ concentration (Table 1 and Additional file 1b). Figure 2 indicates that the transcript levels of PhoB regulated genes such as $p h o A, p h o E$, $p h o H$, pstS, ugpB and $p h o M$ were down-regulated, whereas phoR and phou changed little, as compared to those of wild type. In a similar fashion as the wild type, the transcript level of $\operatorname{arcA}$ increased while $\mathrm{cra}$ decreased as $\mathrm{P}$ concentration decreased for the $p h o B$ mutant, which implies that those phenomena are $p h o B$ independent. The transcript levels of sox $R$ and rpoS increased and $\operatorname{sod} A$ as well as respiratory chain genes such as $c y o A, n d h$ and $n u о A$ increased in a similar fashion as $\mathrm{P}$ concentration decreased for the $p h o B$ mutant, which implies that the activation of the respiratory chain is phoB-independent, but P-concentration dependent.

In order to confirm the result for phoB mutant, the effect of phoR gene knockout on fermentation characteristics and some selected gene transcript levels were also investigated for the case of $10 \%$ of $\mathrm{P}$ concentration as given in Table 1 and Figure 3. Table 1 indicates that the cell concentration and the glucose concentration for $p h o R$ mutant are similar to those of $p h o B$ mutant, whereas acetate concentration became quite low at P-limiting condition for the phoR mutant. Figure 3 indicates that the $p h o B$ regulated genes such as phoA, phoE, phoH, phnC, pstS, $u g p B$ were more down-regulated for the $p h o R$ mutant as compared to phoB mutant, whereas phoU and phoM $(\mathrm{creC})$ were less affected by phoR gene knockout.

\section{Effect of culture $\mathrm{pH}$ and phosphate limitation on the metabolism}

Table 2 shows the effect of $\mathrm{pH}$ and phosphate limitation on the fermentation characteristics in the continuous culture of $E$. coli at the dilution rate of $0.2 \mathrm{~h}^{-1}$, where it 
Table 1 Fermentation characteristics of the wild type $E$. coli and its phoB and phoR mutants in the aerobic chemostat culture under different phosphate concentrations at the dilution rate of $0.2 \mathrm{~h}^{-1}$ at $\mathrm{pH} 7.0$

\begin{tabular}{|c|c|c|c|c|c|c|c|c|c|}
\hline Fermentation Parameters & & $\begin{array}{l}\text { P-rich }(100 \%) \\
\text { condition }\end{array}$ & $\begin{array}{l}\text { P-lower }(55 \%) \\
\text { condition }\end{array}$ & $\begin{array}{l}\text { P-limited (20\%) } \\
\text { condition }\end{array}$ & $\begin{array}{l}\text { P-limited (15\%) } \\
\text { condition }\end{array}$ & $\begin{array}{l}\text { P-limited (12.5\%) } \\
\text { condition }\end{array}$ & $\begin{array}{l}\text { P-limited (10\%) } \\
\text { condition }\end{array}$ & $\begin{array}{l}\text { P-limited (5\%) } \\
\text { condition }\end{array}$ & $\begin{array}{l}\text { P-limited (1\%) } \\
\text { condition }\end{array}$ \\
\hline \multirow[t]{3}{*}{ Biomass concentration $(\mathrm{g} / \mathrm{l})$} & Wild & $3.86 \pm 0.03$ & $3.68 \pm 0.05$ & $3.47 \pm 0.05$ & $3.08 \pm 0.02$ & $2.78 \pm 0.03$ & $1.69 \pm 0.03$ & - & - \\
\hline & $\Delta p h o B$ & $3.44 \pm 0.04$ & $3.560 \pm 0.011$ & - & - & - & $3.64 \pm 0.01$ & $3.24 \pm 0.02$ & $0.050 \pm 0.001$ \\
\hline & $\Delta p h o R$ & - & - & - & - & - & $3.710 \pm 0.112$ & - & - \\
\hline \multirow[t]{3}{*}{ Glucose concentration (g/l) } & Wild & $0.660 \pm 0.004$ & $0.760 \pm 0.004$ & $0.557 \pm 0.001$ & $0.700 \pm 0.003$ & $0.700 \pm 0.003$ & $1.85 \pm 0.01$ & - & - \\
\hline & $\Delta p h o B$ & $1.59 \pm 0.29$ & $1.66 \pm 0.23$ & - & - & - & $1.050 \pm 0.001$ & $1.330 \pm 0.001$ & $9.960 \pm 0.001$ \\
\hline & $\Delta p h o R$ & - & - & - & - & - & $0.910 \pm 0.004$ & - & - \\
\hline \multirow[t]{3}{*}{ Acetate concentration $(\mathrm{g} / \mathrm{l})$} & Wild & $0.046 \pm 0.002$ & $0.042 \pm 0.001$ & $0.410 \pm 0.001$ & $0.43 \pm 0.07$ & $0.41 \pm 0.03$ & $0.41 \pm 0.02$ & - & - \\
\hline & $\Delta p h o B$ & $0.255 \pm 0.130$ & $0.233 \pm 0.030$ & - & - & - & $0.346 \pm 0.010$ & $0.440 \pm 0.010$ & $0.002 \pm 0.002$ \\
\hline & $\Delta p h o R$ & - & - & - & - & - & $0.0035 \pm 0.0010$ & - & - \\
\hline \multirow{3}{*}{$\begin{array}{l}\text { Specific glucose uptake rate } \\
(\mathrm{mmol} / \mathrm{gDCW} / \mathrm{h})\end{array}$} & Wild & $2.69 \pm 0.05$ & $2.79 \pm 0.02$ & $3.024 \pm 0.005$ & $3.350 \pm 0.001$ & $3.717 \pm 0.002$ & $5.36 \pm 0.01$ & - & - \\
\hline & $\Delta p h o B$ & $2.72 \pm 0.09$ & $2.60 \pm 0.07$ & - & - & - & $2.730 \pm 0.003$ & $2.970 \pm 0.001$ & $0.890 \pm 0.001$ \\
\hline & $\Delta p h o R$ & - & - & - & - & - & $2.70 \pm 0.004$ & - & - \\
\hline \multirow[t]{3}{*}{$\begin{array}{l}\text { Specific acetate production rate } \\
(\mathrm{mmol} / \mathrm{gDCW} / \mathrm{h})\end{array}$} & Wild & $0.040 \pm 0.002$ & $\begin{array}{c}0.0380 \pm \\
0.0001\end{array}$ & $0.394 \pm 0.010$ & $0.465 \pm 0.003$ & $0.491 \pm 0.030$ & $0.81 \pm 0.02$ & - & - \\
\hline & $\Delta p h o B$ & $0.247 \pm 0.080$ & $0.218 \pm 0.033$ & - & - & - & $0.317 \pm 0.001$ & $0.452 \pm 0.010$ & $0.133 \pm 0.002$ \\
\hline & $\Delta p h o R$ & - & - & - & - & - & $0.0031 \pm 0.0010$ & - & - \\
\hline
\end{tabular}

Note: " - " indicates that no data was collected for this condition. The standard deviation was obtained by triplicate measurements. 


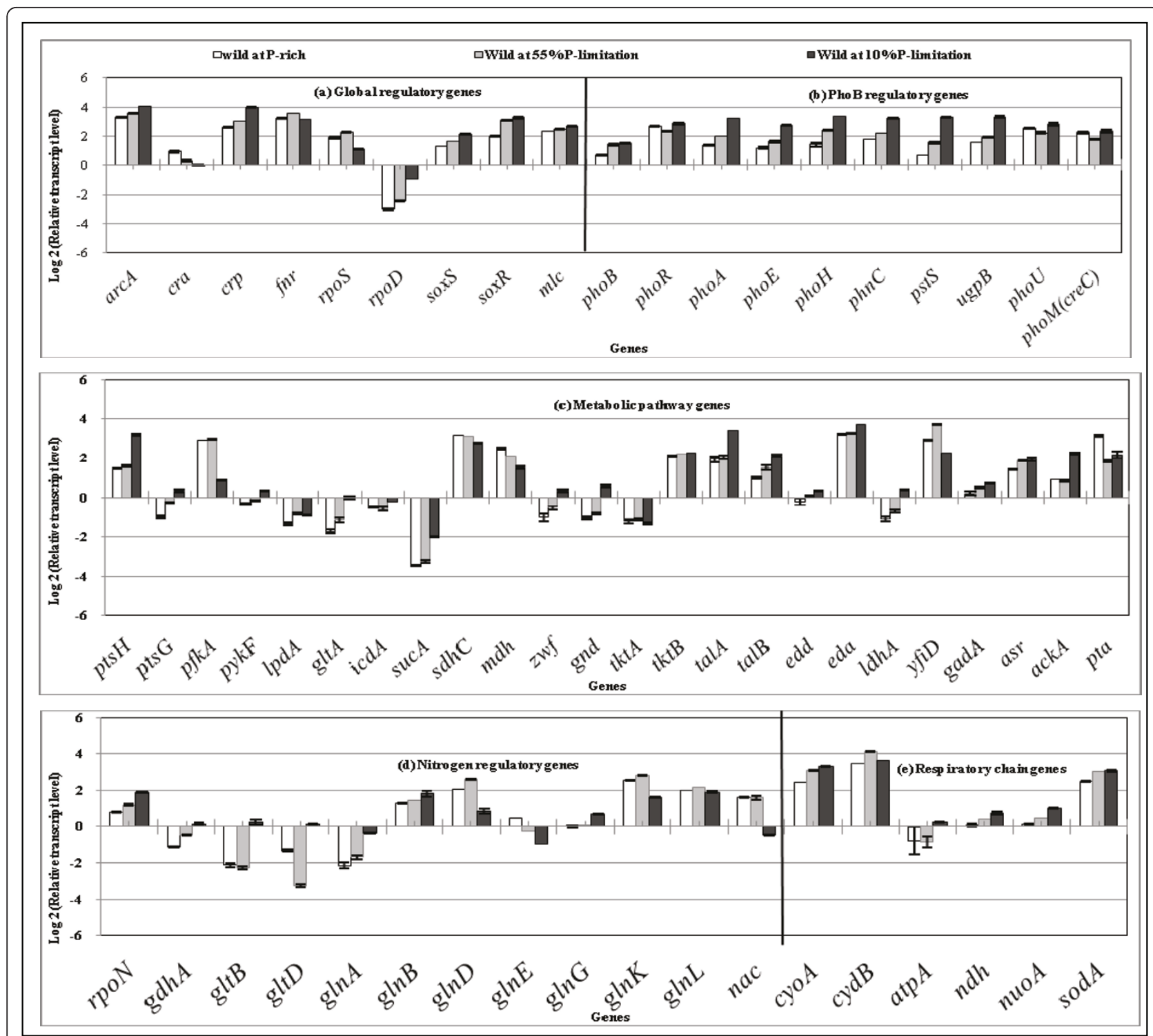

Figure 1 Comparison of the transcript levels of the wild type $E$. coli cultivated with different $P$ concentrations of the feed $(100 \%, 55 \%$, 10\%): (a) global regulatory genes, (b) PhoB regulatory genes, (c) metabolic pathway genes, (d) nitrogen regulatory genes, and (e) respiratory chain genes.

indicates that more acetate was formed with higher glucose uptake rate, while the cell concentration became lower at pH 6.0 as compared to the case of $\mathrm{pH} 7.0$. Note that the fermentation characteristics were different even between $100 \%$ and $55 \%$ of phosphate concentration under lower $\mathrm{pH}$ value. Figure 4 shows the effect of culture $\mathrm{pH}$ on the transcript levels, where it indicates that $\operatorname{arcA}$ gene was up-regulated $(\mathrm{P}<0.01)$, and the TCA cycle genes such as $s d h C$ and $m d h$ were down-regulated accordingly $(\mathrm{P}<0.01$ and $\mathrm{P}<0.01$, respectively). Note that icdA gene was up-regulated $(\mathrm{P}<0.01)$, which coincided with the up-regulation of $\mathrm{cra}$ gene $(\mathrm{P}<0.01)$ (Additional file 2). Figure 4 also shows that the transcript level of rpoS was up-regulated, and the expression of $\mathrm{gadA}$ (glutamate decarboxylase) gene was up-regulated at $\mathrm{pH} 6.0$ [38]. The $y$ fiD gene, which encodes acid-inducible protein [39], was also up-regulated at lower $\mathrm{pH}$. Figure 4 also shows that $p h o B$ gene was up-regulated and the $\mathrm{PhoB}$ regulated genes such as phoA, phoE, phoH, phnC, pstS, and ugpB as well as phoR, phou, phoM and eda were up-regulated $(\mathrm{P}<0.01$ for all genes). This means that acid stress and phosphate regulation are directly or indirectly interconnected [4].

Figure 4 also shows the effects of lower $\mathrm{pH}$ and lower P-concentration on the transcript levels ( $3^{\text {rd }}$ bars), where $p h o B$ gene was further up-regulated, and the Pho 


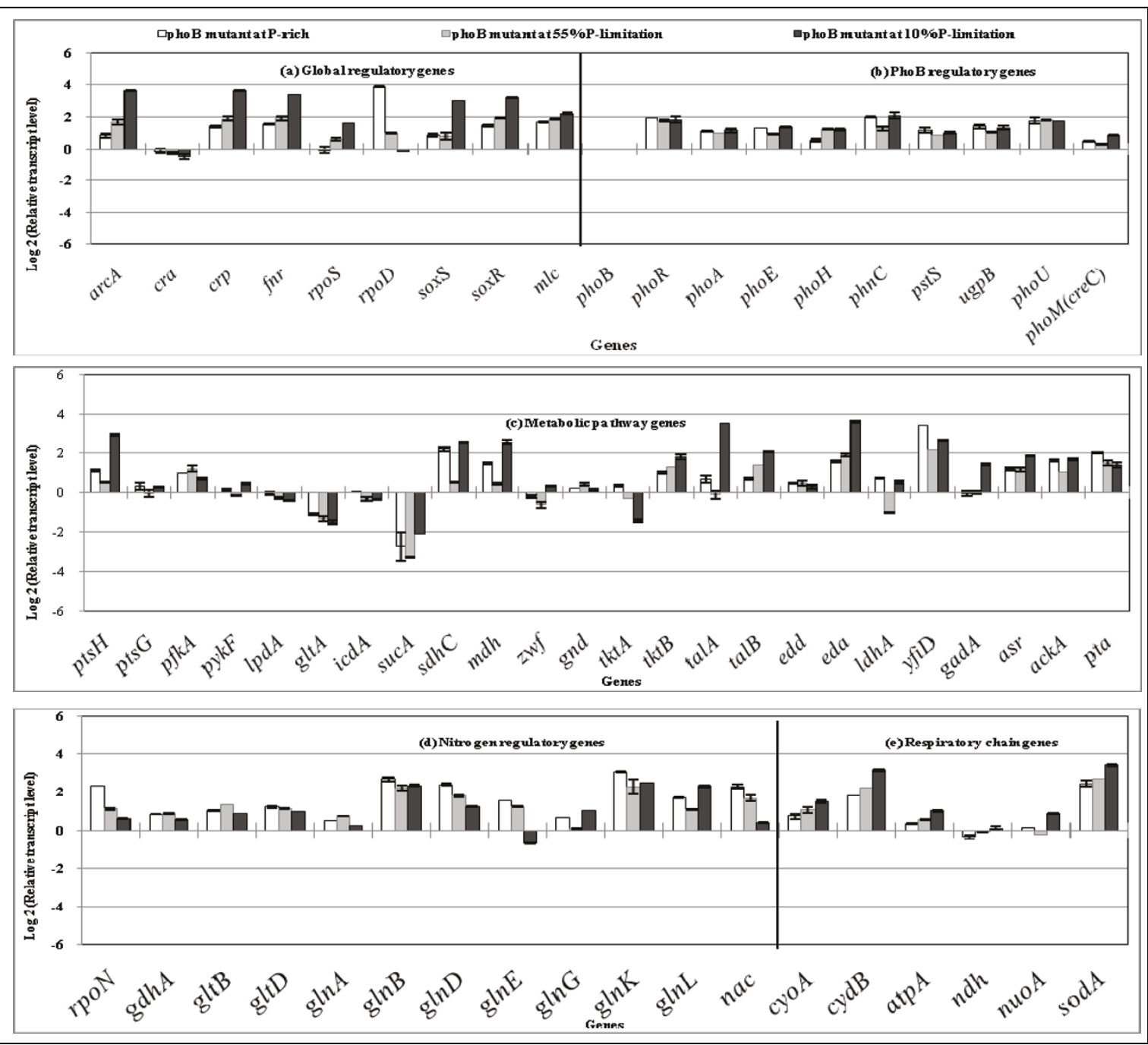

Figure 2 Comparison of the transcript levels of the phoB mutant $E$. coli cultivated with different $\mathrm{P}$ concentrations of the feed (100\%, 55\%, 10\%): (a) global regulatory genes, (b) PhoB regulatory genes, (c) metabolic pathway genes, (d) nitrogen regulatory, and (e) respiratory chain genes.

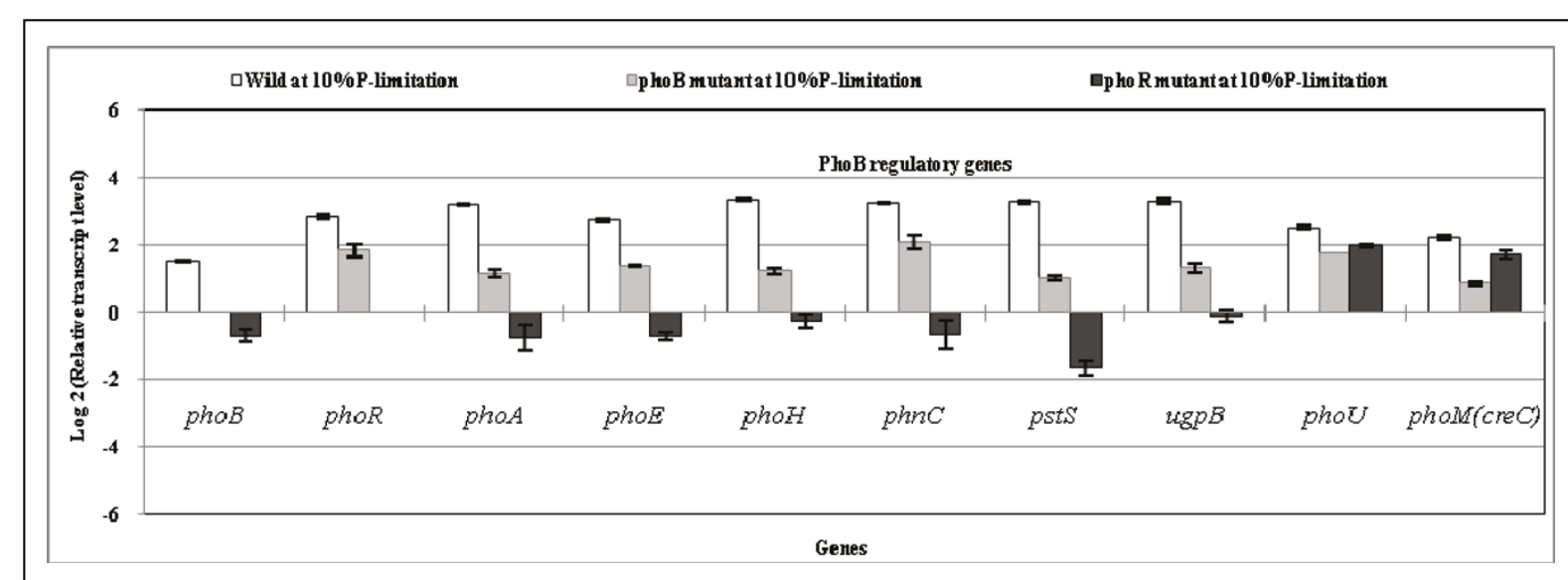

Figure 3 Comparison of the transcript levels of Pho regulon genes for the wild type, phoB and phoR mutants cultivated at $10 \% \mathrm{P}$ concentration. 
Table 2 Fermentation characteristics of the wild type $E$. coli and its phoB mutant in the aerobic chemostat culture under two phosphate concentrations $(100 \%$ and $55 \%)$ and two pH values $(7.0$ and 6.0$)$ at the dilution rate of $0.2 \mathrm{~h}^{-1}$

\begin{tabular}{|c|c|c|c|c|}
\hline \multicolumn{2}{|l|}{ Fermentation parameters } & \multicolumn{2}{|c|}{ P-rich condition (100\%) } & \multirow{2}{*}{$\begin{array}{c}\text { Lower P concentration }(55 \% \\
\mathrm{pH} 6.0\end{array}$} \\
\hline & & $\mathrm{pH} 7.0$ & $\mathrm{pH} 6.0$ & \\
\hline \multirow[t]{2}{*}{ Biomass concentration $(\mathrm{g} / \mathrm{l})$} & Wild & $3.86 \pm 0.03$ & $3.680 \pm 0.002$ & $1.960 \pm 0.001$ \\
\hline & $\Delta p h o B$ & $3.44 \pm 0.04$ & - & $3.040 \pm 0.001$ \\
\hline \multirow[t]{2}{*}{ Glucose concentration (g/l) } & Wild & $0.660 \pm 0.004$ & $1.053 \pm 0.010$ & $0.677 \pm 0.050$ \\
\hline & $\Delta p h o B$ & $1.59 \pm 0.29$ & - & $1.145 \pm 0.020$ \\
\hline \multirow[t]{2}{*}{ Acetate concentration $(\mathrm{g} / \mathrm{l})$} & Wild & $0.046 \pm 0.002$ & $0.468 \pm 0.003$ & $0.519 \pm 0.001$ \\
\hline & $\Delta p h o B$ & $0.255 \pm 0.130$ & - & $0.510 \pm 0.007$ \\
\hline \multirow[t]{2}{*}{ Specific glucose uptake rate (mmol/gDCW/h) } & Wild & $2.69 \pm 0.05$ & $2.700 \pm 0.001$ & $5.285 \pm 0.031$ \\
\hline & $\Delta p h o B$ & $2.72 \pm 0.09$ & - & $3.24 \pm 0.01$ \\
\hline \multirow[t]{2}{*}{ Specific acetate production rate (mmol/gDCW/h) } & Wild & $0.040 \pm 0.002$ & $0.424 \pm 0.003$ & $0.882 \pm 0.001$ \\
\hline & $\Delta p h o B$ & $0.247 \pm 0.080$ & _ & $0.559 \pm 0.007$ \\
\hline
\end{tabular}

Note: " - " indicates that no data was collected for this condition. The standard deviation was obtained by triplicate measurements.

regulon genes such as $p h o R, p h o H, p h n C$, pstS, ugpB, and phoU were all further up-regulated at lower $\mathrm{P}$ concentration at $\mathrm{pH}$ 6.0. The rpoS gene further increased (P $<0.01$ ), and $\operatorname{gad} A$ gene was also further up-regulated ( $\mathrm{P}$ $<0.01)$. Figure 4 shows that $\operatorname{arc} A$ transcript level tended to be up-regulated though not significant, and this may have caused down-regulations of $s d h C$ and $m d h(\mathrm{P}<$ 0.01 and $\mathrm{P}<0.01$, respectively) under $\mathrm{P}$-limitation as compared to P-rich condition at acidic condition.

Table 2 shows the effects of lowering $\mathrm{pH}$ and $\mathrm{P}$ concentration on the fermentation characteristics of $p h o B$ gene knockout mutant as well, where it indicates that

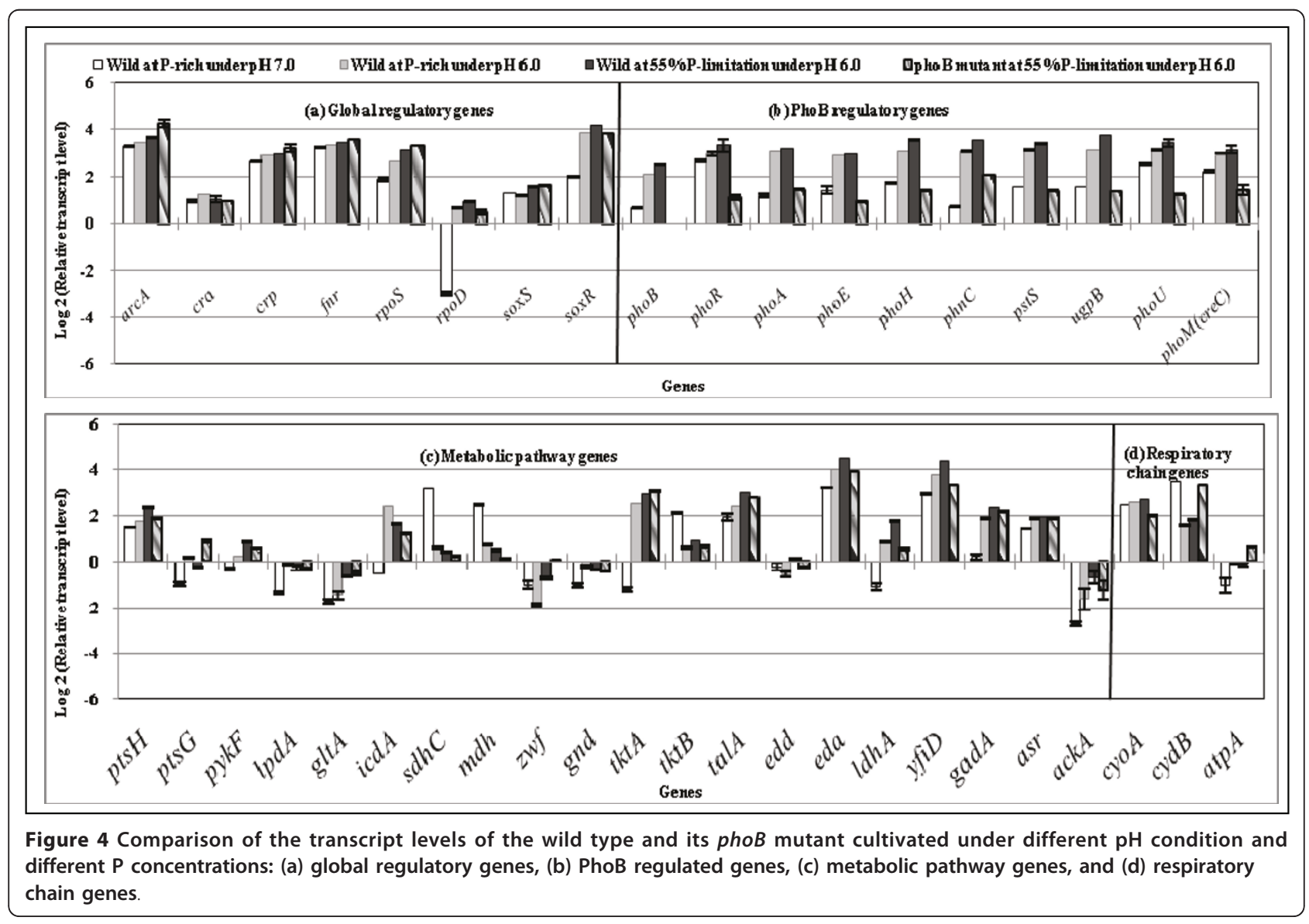


the glucose concentration increased for the phoB mutant as compared to the wild type under both $\mathrm{pH} 7.0$ and 6.0. Figure 4 shows the comparison of the transcript levels between the wild type ( $3^{\text {rd }}$ bars) and its $p h o B$ mutant ( $4^{\text {th }}$ bars) at $\mathrm{pH} 6.0$, where it indicates that the phoB regulated genes such as $p h o A$, phoE, phoH, phnC, pstS, $\operatorname{ugp} B(\mathrm{P}<0.01$ for all genes $)$ as well as phoR, phou, phoM and eda were all significantly down-regulated ( $\mathrm{P}<0.01$ for all genes) for the $p h o B$ mutant. The transcript levels of TCA cycle genes such as $s d h C$ and $m d h$ were down-regulated for the $p h o B$ mutant as compared to the wild type.

\section{Effect of nitrogen limitation}

Table 3 shows the effect of nitrogen (N) limitation and lower $\mathrm{P}$ concentration on the fermentation characteristics, where the specific glucose consumption rate and the specific acetate production rate increased, while cell concentration decreased for the case of $\mathrm{N}$-limitation as compared to $\mathrm{N}$-rich condition. Those changes were further enhanced at lower P concentration. Figure 5 shows the effect of N-limitation on the transcript levels of several genes, where it indicates that rpoN transcript level increased and $g \ln A, L, G, g l t B, g \ln D, g \ln K$ and $n a c$ genes were up-regulated $(\mathrm{P}<0.01$ for all genes), while $g \ln E$ gene was down-regulated $(\mathrm{P}<0.01)$. Figure 5 also shows that the transcript level of $p h o B$ gene was upregulated and $\mathrm{PhoB}$ regulated genes such as phoA, phoE, phoH, phnC, pstS were increased ( $\mathrm{P}<0.01$ for all genes) as well as phoR, phou, and phoM $(\mathrm{P}<0.01$ for all genes) under $\mathrm{N}$-limitation as compared to $\mathrm{N}$-rich condition. The TCA cycle genes such as $s d h C$ and $m d h$ decreased $(\mathrm{P}<0.01$ for both genes), which may have caused TCA cycle to be repressed, which corresponds to the increase in the specific acetate production rate. The $p t s G, p t s H$ and $p f k A$ gene expressions increased $(\mathrm{P}<$ 0.01 for all genes), which corresponds to the increase in the specific glucose consumption rate. The transcript levels of $f n r$ and $y f i D$ were up-regulated $(\mathrm{P}<0.01$ for both genes) in a similar fashion. Moreover sox $R$ increased and the respiratory chain genes such as cyoA, $c y d B$, ndh and $n u o A$ as well as $\operatorname{sod} A$ were all upregulated under $\mathrm{N}$-limitation $(\mathrm{P}<0.01$ for all genes).

Table 3 also shows the effect of lower $P$ concentration on the fermentation characteristics of phoB mutant under N-limitation, where it indicates that the cell concentration decreased, while acetate and glucose concentrations increased under $\mathrm{N}$-limitation as compared to $\mathrm{N}$-rich condition for the $p h o B$ mutant. Figure 5 indicates (by comparison of the $2^{\text {nd }}$ and $3^{\text {rd }}$ bars) that phoB regulated genes such as phoA, phoE, phnC, pstS, phoR, phou, ( $\mathrm{P}<0.01$ for all genes $)$ as well as $p h o H$ and phoM were down-regulated ( $\mathrm{P}<0.05$ for the two genes) as compared to the wild type. Although rpoN transcript level changed little, such genes as $g \ln D, g \ln G, g \ln L$ were up-regulated $(\mathrm{P}<0.01$ for all genes), whereas $g l t D(\mathrm{P}<$ $0.5)$, and $g \ln A, g \ln E, g \ln K$, nac genes were down-regulated ( $\mathrm{P}<0.01$ for all genes).

\section{Discussion}

It was shown that the glycolysis was activated under phosphate limiting condition by the data of the specific growth rate (Table 1) and by the corresponding gene transcript levels (Figure 1). This may be due to ATP demand caused by the decrease in ATP formation with limited amount of available phosphate as implied by Kobeman et al. [40] who investigated the effect of [ATP]/[ADP] ratio on the glycolytic flux. The lower cell concentration under P-limitation may also be due to lower ATP formation as we investigated previously on

Table 3 Fermentation characteristics of the wild type $E$. coli and its phoB mutant in the aerobic chemostat culture under different nitrogen and phosphate concentrations at the dilution rate of $0.2 \mathbf{h}^{-1}$ at $\mathbf{p H} 7.0$

\begin{tabular}{|c|c|c|c|c|}
\hline Fermentation parameters & & $\begin{array}{l}\mathrm{N} \text { and P-rich condition } \\
(100 \%)\end{array}$ & $\begin{array}{l}\mathrm{N} \text {-limited }(20 \%) \text { and P-rich } \\
\text { condition }\end{array}$ & $\begin{array}{l}\mathrm{N} \text {-limited }(20 \%) \text { and lower } \mathrm{P} \\
\text { concentration }(55 \%)\end{array}$ \\
\hline \multirow[t]{2}{*}{ Biomass concentration $(\mathrm{g} / \mathrm{l})$} & Wild & $3.86 \pm 0.03$ & $1.753 \pm 0.005$ & $1.68 \pm 0.01$ \\
\hline & $\triangle p h o B$ & $3.44 \pm 0.04$ & $1.703 \pm 0.005$ & $1.59 \pm 0.01$ \\
\hline \multirow[t]{2}{*}{ Glucose concentration $(\mathrm{g} / \mathrm{l})$} & Wild & $0.660 \pm 0.004$ & $5.39 \pm 0.01$ & $4.10 \pm 0.01$ \\
\hline & $\triangle p h o B$ & $1.59 \pm 0.29$ & $2.890 \pm 0.006$ & $4.81 \pm 0.01$ \\
\hline \multirow[t]{2}{*}{ Acetate concentration $(\mathrm{g} / \mathrm{l})$} & Wild & $0.046 \pm 0.002$ & $0.486 \pm 0.002$ & $0.502 \pm 0.004$ \\
\hline & $\triangle p h o B$ & $0.255 \pm 0.130$ & $0.475 \pm 0.004$ & $0.495 \pm 0.010$ \\
\hline \multirow{2}{*}{$\begin{array}{l}\text { Specific glucose uptake rate (mmol/ } \\
\text { gDCW/h) }\end{array}$} & Wild & $2.69 \pm 0.05$ & $2.92 \pm 0.01$ & $3.90 \pm 0.01$ \\
\hline & $\triangle p h o B$ & $2.72 \pm 0.09$ & $4.64 \pm 0.01$ & $3.63 \pm 0.02$ \\
\hline \multirow{2}{*}{$\begin{array}{l}\text { Specific acetate production rate } \\
\qquad(\mathrm{mmol} / \mathrm{gDCW} / \mathrm{h})\end{array}$} & Wild & $0.040 \pm 0.002$ & $0.923 \pm 0.010$ & $0.995 \pm 0.010$ \\
\hline & $\overline{\Delta p h o B}$ & $0.247 \pm 0.080$ & $0.928 \pm 0.010$ & $1.037 \pm 0.020$ \\
\hline
\end{tabular}

Note: The standard deviation was obtained by triplicate measurements. 


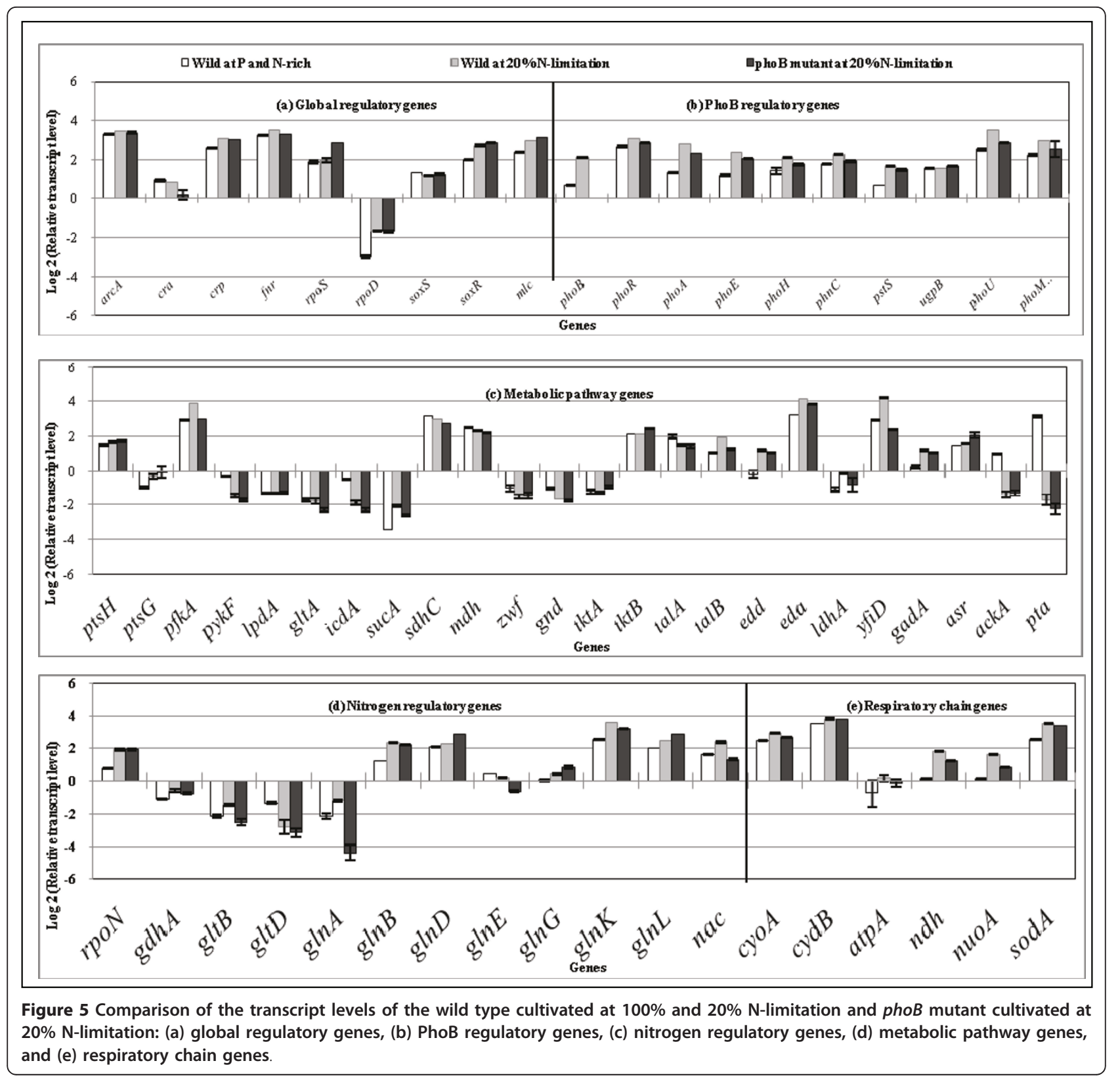

the relationship between the cell growth rate and the specific ATP production rate [41,42].

Moreover, phosphate limitation causes less ATP production by $\mathrm{H}^{+}$-ATPase, which causes less quinol oxidation by Cyo, which in turn affected quinone pool size, and thus activate ArcA/B, which represses the TCA cycle genes, and in turn produced more acetate. The similar situation has also been seen in $c y o A$ and $c y d B$ genes knockout mutants in our previous investigation [43].

Figure $1 \mathrm{~b}$ indicates that $p h o B$ gene transcript level increased as $\mathrm{P}$ concentration decreases in the wild type, and Figure 1a indicates that rpoD also increased as $\mathrm{P}$ concentration decreases. The phoA, phoE, phoH, phnC, $p s t S$, and $u g p B$ were all increased in a similar fashion as that of rpoD as mentioned in the result section. Figure 1a indicates that the expression pattern of rpoS is somewhat different. When cells enter into $P_{\mathrm{i}}$-starvation phase in the batch culture, the Pho regulon is activated, and $\sigma^{\mathrm{S}}$ starts to accumulate in the cytosol $[1,44,45]$. The promoters of the Pho genes are recognized by $\sigma^{\mathrm{D}}$ - associated RNA polymerase. A mutation in rpoS, significantly increases the level of AP (Alkaline phosphatase) activity, and the overexpression of $\sigma^{\mathrm{S}}$ inhibits it [46]. It has been reported that in rpoS mutant, the expression of AP was considerably higher than in wild-type strain, implying that $\sigma^{\mathrm{S}}$ is 
involved in the regulation of AP. Other Pho genes such as $p h o E$ and $u g p B$ are likewise affected by $\sigma^{\mathrm{S}}$. The rpoS may inhibit the transcriptions of $p h o A$, phoB, phoE, and $u g p B$, but not that of pstS [46]. Figure 1ab indicates that Pho genes are highly expressed as compared to low rpoS transcript level in the case of P-limitation. In contrast, pst may be transcribed by both $\sigma^{\mathrm{S}}$ and $\sigma^{\mathrm{D}}$. The Pho regulon is thus evolved to maintain a trade-off between cell nutrition and cell survival during $\mathrm{P}_{\mathrm{i}}$-starvation [46]. The previous reports suggest that the Pho regulon and the stress response are interrelated [45-50].

E. coli cells have been demonstrated to exhibit acid resistance by such genes as $\operatorname{gad} A B$ which encode glutamate decarboxylase and gad $C$ which encodes glutamate: $\gamma$ amino butyric acid (GABA) antiporter. Glutamate decarboxylase production has been shown to increase in response to acid, osmotic and stationary phase signals $[51,52]$. In the typical batch culture, organic acids are most accumulated at the late growth phase or the stationary phase. It was shown that $\operatorname{gad} A$ was PhoB-dependently upregulated in the present study (Figure 4), and this indicates that this gene is indirectly regulated by PhoB. Note that Figure 4 indicates that gadA gene expression decreased for the $p h o B$ mutant under acidic condition $\left(4^{\text {th }}\right.$ bar), while rpoS increased. This suggests that phosphate starvation and acid stress responses may be interconnected [4].

Figure 4 also indicates that $y f i D$ transcript level increased at acidic condition. It has been shown that the expression of $y f i D$ gene is induced at acidic condition, and this reduces the accumulation of acidic metabolite and products [39]. The anaerobic transcription factor Fnr (Fumarate and nitrate reduction regulator) has been shown to be the major regulator of $y f i D$ expression, and ArcA was shown to enhance anaerobic yfiD expression [39]. Figure 4 indicates that $y f i D$ transcript level changed in a similar fashion as $r p o D$ rather than $\operatorname{arc} A$ and $f n r$. It has been known that the transcriptional regulator Fnr of $E$. coli functions as an $\mathrm{O}_{2}$ sensor, and the protein is in the active form and predominately exists as a homodimer with one $[4 \mathrm{Fe}-4 \mathrm{~S}]$ cluster per monomer under anoxic conditions. In the presence of oxygen, $[4 \mathrm{Fe}-4 \mathrm{~S}]$ FNR is converted to [2Fe-2S] FNR cluster and finally to apoFnr, which is no longer active in gene regulation $[53,54]$. Nevertheless, fnr gene transcript level changed, which indicates that Fnr does not play its conventional role, and may have some role under aerobiosis, but it is not clear at this stage. Figure 4 also indicates that $\operatorname{sox} R$ increased at acidic condition. The acidic condition may affect membrane properties such as lipid content, thus effectively changing the proton permeability. The increased expression of soxR regulates the removal of damaging oxidizing agents [55].

As expected, the acid inducible asr gene transcript level increased at $\mathrm{pH} 6.0$ as compared to the case at $\mathrm{pH}$
7.0 as shown in Figure 4c. The asr gene has been reported to be under the transcriptional control of the PhoR/PhoB two component system in E. coli [56]. Figure 1c indicates that asr gene transcript level increased as $\mathrm{P}$ concentration decreases in accordance with the change in $p h o B$ transcript level. Asr is thought to play a role similar to that of the E. coli periplasmic protein HdeA, which serves as a proton sink or a chaperone for protecting periplasmic proteins from the deleterious effects at lower $\mathrm{pH}$ [57]. As another example, the PhoR/ PhoB system has been suggested to sense external acidity and regulate the transcription of genes that are important for acid shock resistance [56,58-61].

The presence of glucose or mutations in cya or cAMP receptor protein $(\mathrm{crp})$ gene leads to induction of $p h o A$ gene in $p h o R$ mutant. This induction requires the sensor PhoM (CreC) and the regulator PhoB [62]. However, PhoM (CreC) may not detect glucose per se, where it may detect an intermediate in the central metabolism. Therefore, cya or crp mutation may indirectly affect PhoM (CreC) - dependent control. In addition to $P_{i}$ control, two $\mathrm{P}_{\mathrm{i}}$-independent controls may lead to activation of PhoB. These two may be connected to control pathways in carbon and energy metabolisms, in which intracellular $P_{i}$ is incorporated into ATP. One $P_{i}$ independent control is the regulation by the synthesis of AcP, where $\mathrm{P}_{\mathrm{i}}$ is incorporated into ATP at Ack (acetate kinase) pathway. AcP may act indirectly on PhoB.

In E. coli, assimilation of $\mathrm{N}$-source such as $\mathrm{NH}_{4}{ }^{+}$ using $\alpha-K G$ results in the synthesis of glutamate and glutamine. Glutamine synthetase (GS encoded by $\operatorname{gn} A$ ) catalyzes the only pathway for glutamine biosynthesis. Glutamate can be synthesized by two pathways through combined actions of GS and glutamate synthase (GOGAT encoded by $g l t B D$ ) forming GS/GOGAT cycle, or by glutamate dehydrogenase (GDH encoded by $g d h A$ ). Under $\mathrm{N}$-limitation, ammonium enters into the cell via AmtB and is converted to Gln by GS, and UTase (encoded by $g \ln E$ ) uridylylates both $\mathrm{G} \ln \mathrm{K}$ (encoded by $g \ln K$ ) and $\mathrm{Gln} B$ (encoded by $g \ln B$ ) [63]. Figure $5 \mathrm{~d}\left(1^{\text {st }}\right.$ and $2^{\text {nd }}$ bars) indicates that rpoN increased under N-limitation, and $g \ln A L G, g \ln B, g \ln K$ as well as nac genes increased as stated above. On the other hand, under N-rich condition, UTase deurydylylates $G \ln K$ and $G \ln B$. GlnK complexes with $A m t B$, thereby inhibiting the transporter via $A m t B$, where $G \ln B$ interacts with $\mathrm{NtrB}$ (encoded by $g \ln L$ ) and activates its phosphatase activity leading to dephosphorylation of NtrC (encoded by $g \ln G$ ), and NtrC- dependent gene expression ceases [63], thus the nitrogen regulation is affected by the phosphorylation caused by the available P source.

Figure $5 \mathrm{~d}\left(2^{\text {nd }}\right.$ and $3^{\text {rd }}$ bars $)$ indicates that $g \ln B$ and $g \ln K$ transcript levels decreased, and $g \ln A$ transcript 
level became lower under P-limitation as compared to $\mathrm{P}$-rich condition under $\mathrm{N}$-limitation. In the case under $\mathrm{N}$-limitation, $\mathrm{C} / \mathrm{N}$ ratio increases where $\alpha-\mathrm{KG}$ is withdrawn via GDH, which affects the TCA cycle flux. A decreased flow through the TCA cycle would be expected to cause an increase in AcCoA pool and caused more acetate overflow.

Although little research has been done, it is quite important in practice to analyze the metabolism at the late growth phase and the stationary phase in the batch culture, where the medium is nutrient poor indicating carbon, phosphorous, and nitrogen limitations, as well as lower $\mathrm{pH}$. When a particular nutrient becomes limiting, the first response is scavenging. These scavenging regulons include cAMP-Crp which allows for the use of alternative carbon sources such as acetate, and the twocomponent regulatory systems $\mathrm{PhoR} / \mathrm{PhoB}$ and NtrB/ NtrC, which control scavenging for phosphorus and nitrogen, respectively. Both Crp and Ntr systems survey nutrient status through intracellular metabolites, where Crp recognizes cAMP, while $\mathrm{NtrC}$ responds to glutamine. The Pho system, on the other hand, monitors inorganic phosphate levels via the activity of the Pst transport system [1]. The sigma factor responsible for the general stress resistance is $\operatorname{RpoS}\left(\sigma^{38}\right)$ upon starvation. Note that the housekeeping sigma factor $\operatorname{RpoD}\left(\sigma^{70}\right)$ is homologous to RpoS. Carbon starvation is one of the strongest inducers of RpoS, where regulation of RpoS occurs at the level of proteolysis by $\mathrm{C} 1 \mathrm{pXP}$. This regulation is made by sprE, which encodes a response regulator SprE (also called RssB) [64]. RpoS plays also an important role under phosphate limiting condition. However, its regulation mechanism is different. Note that while carbon starvation completely shuts down the central metabolism, it continues upon phosphate starvation [65]. In contrast to carbon and nitrogen starvation, the PhoR/PhoB two component system, either directly or indirectly regulates the translation of rpoS mRNA [45]. Since PhoB is a transcriptional regulator, its effects on rpoS translation may be indirect, where small noncoding RNAs (sRNAs) are important regulators of translation of mRNA. The sRNAs require the RNA chaperone $\mathrm{Hfq}$ for the formation of the RNA-RNA duplex, and there are several RNAs known to affect rpoS translation [66]. Namely, impeding phosphorous starvation is sensed as diminished activity of the Pst transporter, which causes autophosphorylation of PhoR, which then phosphorylate PhoB. The phosphorylated PhoB directly or indirectly activates transcription of an sRNA that stimulates translation of rpos mRNA, thus elevating levels of RpoS [66]. Note that the regulation may be more complicated, since Figure 2a indicates that rpoS level increased as $\mathrm{P}$ concentration decreases even for the phoB mutant as also noted by Peterson et al. [66].
Upon nitrogen starvation, ppGpp levels were known to increase, and there might be some correlations between levels of ppGpp and RpoS levels. RpoS is not stabilized upon nitrogen starvation like it is upon carbon starvation or phosphate starvation, and thus the regulation mechanism may be different, suggesting an increase in the activity of RpoS. [66]. Similar proteins are induced following starvation for carbon, phosphorous and nitrogen $[67,68]$, where RpoS-dependent genes are induced upon starvation. Although the activity of RpoS seems to be critical for nitrogen starvation, there are many players that affect the competition between RpoS and RpoD, including Rsd, 6S RNA, and ppGpp [66]. The role that the NtrB/C nitrogen scavenging system plays in regulating $\mathrm{RpoS}$ is unclear.

The overall regulation mechanism may be illustrated schematically as Figure 6.

Similar mechanism might exist in phoB mutant E. coli, and further investigation is needed to clarify this.

Finally, it seems to be surprising that $p h o B$ (and also phoR) mutant could survive even under strict $\mathrm{P}$ limiting condition as compared to wild type as shown in Table 1 and Additional file 1. Figure 2 indicates that Pho regulon genes were insensitive to $\mathrm{P}$ concentration as expected, whereas global regulatory genes (Figure 2a), metabolic pathway genes (Figure 2c), and respiratory chain genes (Figure 2e) changed significantly. It has recently been reported that phoB mutant was more sensitive to hydrogen peroxide, but that $p h o B$ mutant was more resistant to high osmolarity and acid conditions compared to the wild type of Vibrio cholerae [69].

\section{Conclusion}

The present investigation clarified the effect of phosphate limitation, nitrogen limitation, and acidic condition on the metabolism in view of gene transcript levels. Moreover, the present study implies that the metabolic regulations under phosphate limitation, nitrogen limitation and acidic condition are interconnected. These phenomena occur at the late growth phase in the batch culture. The present result is useful for the analysis of the metabolism changes during late growth phase and/or stationary phase.

\section{Materials and methods}

\section{Bacterial strains used and culture conditions}

The strains used in the present study were Escherichia coli BW25113 (lacl ${ }^{q} \operatorname{rrnB}_{\mathrm{T14}} \Delta \mathrm{lacZ}_{\mathbf{w J 1 6}}$ hsdR514 $\Delta$ ara$\mathrm{BAD}_{\mathrm{AH} 33} \triangle r h a B A D$ LD78), its $p h o B$ gene knockout mutant (JW0389) and phoR mutant (JW0390). The mutants were constructed by one-step inactivation of chromosomal $p h o B$ and $p h o R$ genes, respectively [70]. Continuous cultivations were carried out in a 2 - $\mathrm{L}$ fermentor (M-100, Tokyo, Rikakiki Co., Tokyo, Japan), 


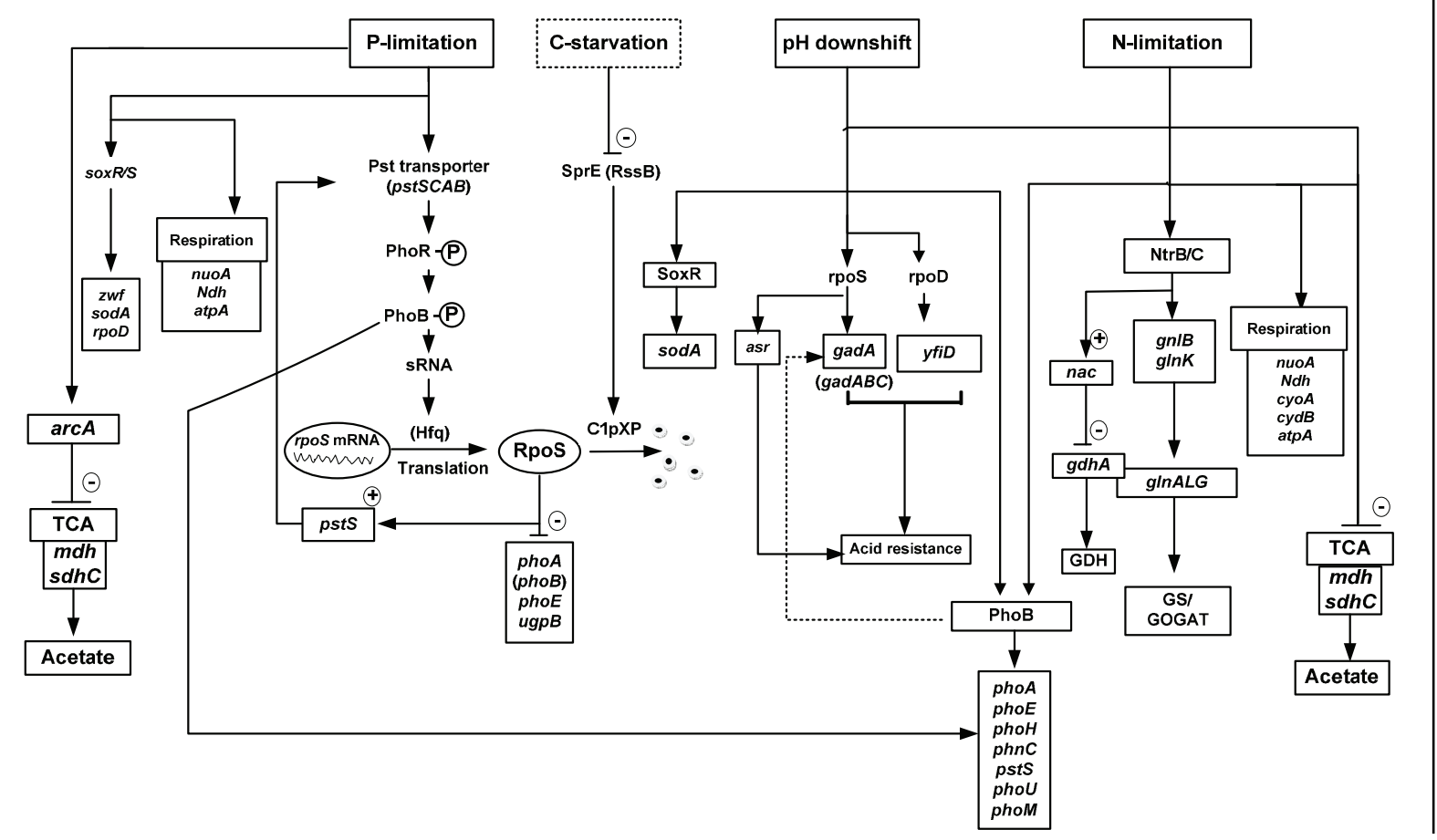

Figure 6 Schematic illustrations for the metabolic regulation mechanism.

where the temperature was kept constant at $37^{\circ} \mathrm{C}$. The $\mathrm{pH}$ of the broth was maintained either at $7.0 \pm 0.1$ or $6.0 \pm 0.1$ with a $\mathrm{pH}$ controller by automatic addition of $2.0 \mathrm{M} \mathrm{HCl}$ or $2.0 \mathrm{M} \mathrm{NaOH}$. The aerobic condition was ascertained by controlling the stirring speed at $350 \mathrm{rpm}$ with the constant air flow rate of $1 \mathrm{~L} \mathrm{~min}^{-1}$, which has been shown to be $30-40 \%$ of air saturation. The $\mathrm{CO}_{2}$ and $\mathrm{O}_{2}$ concentrations were monitored using an off-gas analyzer (BMJ-02 PI, ABLE Co., Japan).

The M9 minimal medium was used where it contained $10 \mathrm{~g}$ of glucose per liter, $48 \mathrm{mM} \mathrm{Na}_{2} \mathrm{HPO}_{4,}, 22 \mathrm{mM}$ $\mathrm{KH}_{2} \mathrm{PO}_{4}, 10 \mathrm{mM} \mathrm{NaCl}$, and $30 \mathrm{mM}\left(\mathrm{NH}_{4}\right)_{2} \mathrm{SO}_{4}$. The following components were filter sterilized and then added (per liter of final medium): $1 \mathrm{ml}$ of $1 \mathrm{M} \mathrm{MgSO}_{4}, 1 \mathrm{ml}$ of $0.1 \mathrm{mM} \mathrm{CaCl}_{2}, 1 \mathrm{ml}$ of $1 \mathrm{mg}$ of vitamin $\mathrm{B} 1$ per liter, and $10 \mathrm{ml}$ of trace element solution containing (per liter) $0.55 \mathrm{~g}$ of $\mathrm{CaCl}_{2} \cdot 2 \mathrm{H}_{2} \mathrm{O}, 1.67 \mathrm{~g}$ of $\mathrm{FeCl}_{3}, 0.10 \mathrm{~g}$ of $\mathrm{MnCl}_{2} .4 \mathrm{H}_{2} \mathrm{O}, 0.17 \mathrm{~g}$ of $\mathrm{ZnCl}_{2}, 0.043 \mathrm{~g}$ of $\mathrm{CuCl}_{2} .2 \mathrm{H}_{2} \mathrm{O}$, $0.06 \mathrm{~g}$ of $\mathrm{CoCl}_{2} \cdot 6 \mathrm{H}_{2} \mathrm{O}$ and $0.06 \mathrm{~g} \mathrm{Na}_{2} \mathrm{MoO}_{4} \cdot 2 \mathrm{H}_{2} \mathrm{O}$. Continuous cultivations were performed at the dilution rate of $0.2 \mathrm{~h}^{-1}$, where the feed glucose concentration was $10 \mathrm{~g} / \mathrm{L}$, and several different phosphate concentrations were considered: P-rich or $100 \% \mathrm{P}$ concentration $(2.99 \mathrm{~g} / \mathrm{L}$ of $\mathrm{KH}_{2} \mathrm{PO}_{4}$ and $6.81 \mathrm{~g} / \mathrm{L}$ of $\left.\mathrm{Na}_{2} \mathrm{HPO}_{4}\right)$ and P-limitation or $10 \%$ of $\mathrm{P}$ concentration $\left(0.229 \mathrm{~g} / \mathrm{L}\right.$ of $\mathrm{KH}_{2} \mathrm{PO}_{4}$ and 0.681 $\mathrm{g} / \mathrm{L}$ of $\mathrm{Na}_{2} \mathrm{HPO}_{4}$ ). Several other $\mathrm{P}$ concentrations in between were also investigated. For the nitrogen limited condition, $6.0 \mathrm{mM}$ of $\left(\mathrm{NH}_{4}\right)_{2} \mathrm{SO}_{4}$ was used instead of
$30.0 \mathrm{mM}$. The continuous (chemostate) culture was controlled by adjusting the rotation speed of input and output pumps of the fermentor, where the rotation speed of output pump was adjusted to keep the broth volume constant, while the rotation speed of input pump was adjusted to set the dilution rate. In the present investigation, the dilution rate was set at $0.2 \mathrm{~h}^{-1}$, where glucose limitation was not observed at such dilution rate. If the dilution rate was decreased less than about $0.1 \mathrm{~h}^{-1}$, the glucose concentration becomes undetectable level, and both glucose and phosphate limitation may occur, and the changes of the transcript levels may be direct or indirect. To avoid such situation, we set the dilution rate to be at $0.2 \mathrm{~h}^{-1}$. The triplicate samples were taken after 4-5 residence times where the steady state was ascertained.

\section{Measurements of biomass and extracellular metabolite concentrations}

Cell concentration was measured by the optical density (OD) of the culture broth at $600 \mathrm{~nm}$ wave length with a spectrophotometer (Ubet-30, Jasco Co., Tokyo, Japan), and then converted to dry cell weight (DCW) per liter based on the relationship between $\mathrm{OD}_{600 \mathrm{~nm}}$ and $\mathrm{DCW}$ previously obtained [71]. Glucose concentration was measured using enzymatic kit (Wako Co., Osaka, Japan). Acetate and lactate concentrations were also measured using enzymatic kits (Boehringer Co., Mannheim, Germany). 
Triplicate measurements were made for each sample to compute the standard deviation.

\section{RNA preparation, design of PCR primers}

Total RNA was isolated from E. coli cells by Qiagen RNeasy Mini Kit (QIAGEN K.K., Japan) according to the manufacturer's recommendation. The quantity and purity of the RNA were determined by the optical density measurements at 260 and $280 \mathrm{~nm}$ and by $1 \%$ formaldehyde agarose gel electrophoresis. Criteria for the design of the gene-specific primer pairs were followed according to Sambrook and Russel [72]. The primers used in this study were described elsewhere [73,74], except those as given in additional file 3 . The primers used in this study were synthesized at Hokkaido System Science Co. (Sapporo, Hokkaido Japan). In all cases, the primer-supplied company confirmed the absolute specificity of the primers.

\section{CDNA synthesis and PCR amplification}

RT-PCR reactions were carried out in a TaKaRa PCR Thermal Cycler (TaKaRa TP240, Japan) using Qiagen One Step RT-PCR Kit (QIAGEN K.K., Japan). The reaction mixture was incubated for $30 \mathrm{~min}$ at $50^{\circ} \mathrm{C}$ for reverse transcription (cDNA synthesis) followed by 15 min incubation at $95^{\circ} \mathrm{C}$ for initial PCR activation. Then the process was subjected to 30 cycles of amplification which consisted of a denaturing step $\left(94^{\circ} \mathrm{C}\right.$ for $\left.1 \mathrm{~min}\right)$, annealing step (approximately $5^{\circ} \mathrm{C}$ below melting temperature, of primers for $1 \mathrm{~min})$, and an extension step $\left(72^{\circ} \mathrm{C}\right.$ for $\left.1 \mathrm{~min}\right)$, and finally the reaction mixture of $25 \mu \mathrm{l}$ was subjected for $10 \mathrm{~min}$ at $72^{\circ} \mathrm{C}$ for final extension. To check for nucleic acid contamination, one negative control was run in every round of RT-PCR. This control lacks the template RNA in order to detect possible contamination of the reaction components. $5 \mu \mathrm{l}$ of amplified products were run on $1.8 \%$ agarose gel. Gels were stained with $1 \mathrm{mg} \mathrm{ml}^{-1}$ of ethidium bromide, photographed using a Digital Image Stocker (DS-30, FAS III, Toyobo, Osaka, Japan) under UV light and analyzed using Gel-Pro Analyzer 3.1 (Toyobo, Osaka, Japan) software. In order to determine the optimal amount of input RNA, the two-fold diluted template RNA was amplified in RT-PCR assay under identical reaction condition to construct a standard curve for each gene product. When the optimal amount of input RNA was determined for each gene product, RT-PCR was carried out under identical reaction condition to detect differential transcript levels of genes. The gene $d n a A$, which encodes $E$. coli DNA polymerase and is not subjected to variable expression, i.e. abundant expression at relatively constant rate in most cells, was used as an internal control in the RT-PCR determinations. The gene expressions are given as relative values to that of $d n a A$. The selection of genes was made based on global regulator-metabolic pathway gene relationships (Additional file 2).

To calculate the standard deviation, RT-PCR was independently performed three times under identical reaction condition. To ensure that the observed expression changes were statistically significant, the Student's t-test was applied.

\section{Additional material}

Additional file 1: Effect of phosphate concentration on the fermentation characteristics of wild type $E$. coli (a) and its phoB mutant (b).

Additional file 2: Global regulators and their regulated genes.

Additional file 3: List of additional primers.

\section{Abbreviations}

a-KG: 2-Ketoglutarate; AcCoA: Acetyl-Coenzyme A; Ack: Acetate kinase; AcP: Acetyl Phosphate; AmtB: Ammonium transport protein; AP: Alkaline phosphatase; ATP: Adenosine Tri-Phosphate; CAMP: Cyclic adenosine monophosphate; CAMP-Crp: CAMP receptor protein; DCW: Dry Cell Weight; [4Fe-4S]: In a number of iron-sulfur proteins; GABA: a-Aminobutyric acid; GDH: Glutamate Dehydrogenase; GIn: Glutamine; GOGAT: Glutamate Syntheses; GS: Glutamine Synthetase; HdeA: Periplasmic protein; N: Nitrogen; OAA: Oxaloacetic Acid; P: Phosphate; PEP: Phospho-enol-pyruvate; ppGpp: Guanosine tetraphosphate; PYR: Pyruvate; TCA: Tri-carboxylic acid; PTS: Phosphotransferase System; UTase: Uridylyltransferase.

\section{Acknowledgements}

This research was supported by Strategic International Cooperative Program, Japan Science and Technology Agency (JST). The authors are pleased to mention about the fruitful discussions with Prof. Johnjoe McFadden of Surrey University and Prof. Hans Westerhoff of Manchester University.

\section{Author details}

${ }^{1}$ Department of Bioscience \& Bioinformatics, Kyushu Institute of Technology, lizuka, Fukuoka 820-8502, Japan. ${ }^{2}$ Institute of Advanced Bioscience, Keio University, Tsuruoka, Yamagata 997-0017, Japan.

\section{Authors' contributions}

LWM carried out fermentation experiments, assayed, made statistical analysis, and drafted the manuscript. KS considered the experimental design, analyzed the result, and prepared the manuscript together with LWM. All authors read and approved the final manuscript.

\section{Competing interests}

The authors declare that they have no competing interests.

Received: 14 January 2011 Accepted: 20 May 2011

Published: 20 May 2011

\section{References}

1. Wanner BL: Phosphorus assimilation and control of the phosphate regulon. In Escherichia coli and Salmonella: Cellular and Molecular Biology. American Society for Microbiology, Washington DC Edited by: Neidhardt FC, Curtiss III R, Ingraham JL, Lin ECC, Low KB, Magasanik B, Reznikoff WS, Riley M, Schaechter M, Umbrager HE 1996, 1357-1381.

2. Lamarche MG, Wanner BL, Sébastien C, Harel J: The phosphate regulon and bacterial virulence: a regulatory network connecting phosphate homeostasis and pathogenesis. FEMS Microbiol Rev 2008, 32(3):461-473.

3. Ishige T, Krause M, Bott M, Wendisch VF, Sahm H: The phosphate starvation stimulon of Corynebacterium glutamicum determined by DNA microarray analyses. J Bacteriol 2003, 185:4519-4529. 
4. Baek JH, Lee SY: Novel gene members in the Pho regulon of Escherichia coli. FEMS Microbiol Lett 2006, 264:104-109.

5. Wendisch VF: Genetic regulation of Corynebacterium glutamicum metabolism. J Microbiol Biotechnol 2006, 16:999-1009.

6. Damoglou AP, Dawes EA: Studies on the lipid content and phosphate requirement for glucose and acetate-grown Escherichia coli. Biochem J $1968,110: 775-781$.

7. Wanner BL: Gene regulation by phosphate in enteric bacteria. J Cell Biochem 1993, 51:47-54.

8. Stock JB, Ninfa A, Stock AM: Protein phosphorylation and the regulation of adaptive responses in bacteria. Microbiol Rev 1989, 53:450-490.

9. Parkinson JS: Signal transduction schemes of bacteria. Cell 1993, 73:857-871.

10. Baek JH, Lee SY: Transcriptome analysis of phosphate starvation response in Escherichia coli. J Microbiol Biotechnol 2007, 17(2):244-252.

11. Smith MW, Payne JW: Expression of periplasmic binding proteins for peptide transport is subject to negative regulation by phosphate limitation in Escherichia coli. FEMS Microbiol Lett 1992, 100:183-190.

12. Harris RM, Webb DC, Howitt SM, Cox GB: Characterization of PitA and PitB from Escherichia coli. J Bacteriol 2001, 183:5008-5014.

13. Blanco AG, Sola M, Gomis-Ruth FX, Coll M: Tandem DNA recognition by PhoB, a two-component signal transduction transcriptional activator. Structure (Cambridge) 2002, 10:701-713.

14. Torriani A, Ludke DN: The Pho regulon of Escherichia coil. In The Molecular Biology of Bacterial Growth. Edited by: Schaechter M, Neidhardt FC, Ingraham J, Kjeldgaard NO. Jones and Bartlett. Boston: MA; 1985:

15. Makino K, Shinagawa H, Nakata A: Regulation of the phosphate regulon of Escherichia coli K-12: regulation and role of the regulatory gene phoR. J Mol Biol 1985, 184:231-240.

16. Makino K, Shinagawa H, Amemura M, Kimura S, Nakata A, Ishihama A: Regulation of the phosphate regulon of Escherichia coli: activation of pstS transcription by PhoB protein in vitro. J Mol Biol 1988, 203:85-95.

17. Makino K, Shinagawa $H$, Amemura M, Kawamoto T, Yamada M, Nakata A: Signal transduction in the phosphate regulon of Escherichia coli involves phosphotransfer between PhoR and PhoB proteins. J Mol Biol 1989, 210:551-559.

18. Shinagawa H, Makino K, Amemura M, Nakata A: Structure and function of the regulatory gene for the phosphate regulon in Escherichia coli. In Phosphate Metabolism and Cellular Regulation in Microorganisms. American Soc for Microbiol. Washington DC Edited by: Torriani-Gorini A, Rothman FG, Silver S, Wright A, Yagil E 1987, 20-25.

19. Wanner BL: Phosphate regulon of gene expression in Escherichia coli. In Escherichia coli and Salmonella typhimurium: Cellular and Mol Biol. American Soc for Microbiol. Washington DC Edited by: Neidhardt FC, Ingraham JL, Low KB, Schaechter M, Umbarger HE 1987, 1326-1333.

20. Amemura M, Makino K, Sinagawa H, Nakata A: Cross talk to the phosphate regulon of Escherichia coli by PhoM protein: PhoM is a histidine protein kinase and catalyzes phosphorylation of PhoB and PhoM-open reading frame 2. J Bacteriol 1990, 172(11):6300-6307.

21. Hsieh YJ, Wanner BL: Global regulation by the seven-component $P_{i}$ signaling system. Current Opin in Microbiol 2010, 13(2):198-203.

22. Van Dien SJ, Keasling JD: A dynamic model of the Escherichia coli phosphate-starvation response. J Theor Biol 1998, 190:37-49.

23. Wanner BL: Phosphate signaling and the control of gene expression in Escherichia coli. In Metal Ions in Gene Regulation. Edited by: Silver S, William W. New York: Chapman and Hall; 1997:104-128.

24. Oganesyan V, Oganesyan N, Adams PD, Jancarik J, Yokota HA, Kim R, Kim SH: Crystal structure of the 'PhoU-like' phosphate uptake regulator from Aquifex aeolicus. J Bacteriol 2005, 187:4238-4244.

25. Nesmeianova MA, Gonina SA, Kulaev IS: Biosynthesis of Escherichia coli polyphosphatases under control of the regulatory genes usual with alkaline phosphatase. Dokl Akad Nauk SSSR 1975, 224(3):710-712.

26. Pratt $C$, Torriani A: Complementation test between alkaline phosphate regulatory mutations phoB and phoRc in Escherichia coli. Genetics 1977, 85:203-208.

27. Zuckier $G$, Ingenito $E$, Torriani A: Pleiotropic effects of alkaline phosphate regulatory mutations $p h O B$ and phoT on anaerobic growth of and polyphosphate synthesis in Escherichia coli. J Bacteriol 1980, 143:934-941.

28. Guan C, Wanner BL, Inouye H: Analysis of regulation of PhoB expression using a phoB-cat fusion. J Bacteriol 1983, 156:710-717.
29. Yamada M, Makino K, Amemura M, Shinagawa H, Nakata A: Regulation of the phosphate regulon of Escherichia coli: Analysis of mutant phoB and phoR genes causing different phenotypes. J Bacteriol 1989, 171:5601-5606.

30. Kimura S, Makino K, Shinagwa H, Amemura M, Nakata A: Regulation of the phosphate regulon of Escherichia coli: characterization of the promoter of the pstS gene. Mol Gen Genet 1989, 215:374-380.

31. Nakata A, Amemura M, Shinagawa H: Regulation of the phosphate regulon in Escherichia coli K-12: Regulation of the negative regulatory gene phoU and identification of the gene product. J Bacteriol 1984, 159(3):979-985.

32. Tsfasman IM, Nesmeianova MA: Membrane proteins in Escherichia coli: effect of orthophosphate and mutation on regulatory genes of secreted alkaline phosphate. Mol Biol (Mosk) 1981, 15(2):298-309.

33. Ault-Richeé $D$, Fraley $C D$, Tzeng CM, Kornberg A: Novel assay reveals multiple pathways regulating stress-induced accumulations of inorganic polyphosphate in Escherichia coli. J Bacteriol 1998, 180:1841-1847.

34. Gharbi S, Belaich A, Murgier M, Lazdunski A: Multiple controls exerted on in vivo expression of the pepN Gene in Escherichia coli: studies with pepN-lacZ operon and protein fusion strains. J Bacteriol 1985, 163:1191-1195

35. Lazzaroni JC, Portailer RC: Regulation of the IkyB gene expression in Escherichia coli K-12 strains carrying an IkyB-lacZ gene fusion. Mol Gen Genet 1985, 201:323-328.

36. Shin PK, Seo JH: Analysis of E. coli phoA-lacZ fusion gene expression inserted into a multicopy plasmid and host cell's chromosome. Biotech and Bioeng 1990, 36(11):1097-1104.

37. Makino K, Amemura M, Kim SK, Nakata A, Shinagawa H: Role of the $\sigma 70$ subunit of RNA polymerase in transcriptional activation by activator protein PhoB in Escherichia coli. Genes Dev 1993, 17(1):149-160.

38. Cheville AM, Arnold KW, Buchrieser C, Cheng C-M, Kaspar CW: rpoS regulation of acid, heat, and salt tolerance in Escherichia coli 0157:H7. Appl and Env Microbiol 1996, 62(5):1822-1824.

39. Wyborn NR, Messenger SL, Henderson RA, Sawers G, Roberts RE, Attwood MM, Green J: Expression of the Escherichia coli yfiD gene responds to intracellular $\mathrm{pH}$ and reduces the accumulation of acidic metabolic end products. Microbiol 2002, 148:1015-1026.

40. Kobemann BJ, Westerhoff HV, Snoep JL, Nilsson D, Jensen PR: The glycolytic flux in Escherichia coli is controlled by the demand for ATP. $J$ of Bacteriol 2002, 184(14):3909-3916

41. Toya $Y$, Ishii N, Nakahigashi K, Soga T, Tomita M, Shimizu K: ${ }^{13} \mathrm{C}$-metabolic flux analysis for batch culture of Escherichia coli and its pyk and pgi gene knockout mutants based on mass isotopomer distribution of intracellular metabolites. Biotech Prog 2010, 26:975-992.

42. Abdul Kadir TA, Mannan AA, Kierzek AM, McFadden J, Shimizu K: Modeling and simulation of the main metabolism in Escherichia coli and its several single-gene knockout mutants with experimental verification. Microb Cell Fact 2010, 9:88.

43. Kumar R, Shimizu K: Transcriptional regulation of main metabolic pathways of $c y o A, c y d B$, fnr, and fur gene knockout Escherichia coli in Climited and N-limited aerobic continuous cultures. Microb Cell Fact 2011, 10:3.

44. Gentry DR, Hernandez VJ, Nguyen LH, Jensen DB, Cashel M: Synthesis of the stationary-phase sigma factor $\sigma^{s}$ is positively regulated by ppGpp. J Bacteriol 1993, 175(24):7982-7989.

45. Ruiz N, Silhavy TJ: Constitutive activation of the Escherichia coli Pho regulon up regulates rpoS translation in an $\mathrm{Hfq}$ dependent fashion. $J$ Bacteriol 2003, 185(20):5984-5992.

46. Taschner NP, Yagil E, Spira B: A differential effect of $\sigma^{\mathrm{S}}$ on the expression of the Pho regulon genes of Escherichia coli. Microbiology 2004, 150:2985-2992.

47. Spira B, Silberstein N, Yagil E: Guanosine 39, 59-bispyrophosphate (ppGpp) synthesis in cells of Escherichia coli starved for $\mathrm{P}_{\mathrm{i}}$.J Bacteriol 1995, 177:4053-4058

48. Spira B, Yagil E: The integration host factor (IHF) affects the expression of the phosphate-binding protein and of alkaline phosphatase in Escherichia coli. Curr Microbiol 1999, 38:80-85.

49. Taschner NP, Yagil E, Spira B: The effect of IHF on $\sigma^{5}$ selectivity of the phoA and pst promoters of Escherichia coli. Arch Microbiol 2006, 185(3):234-237. 
50. Schurdell MS, Woodbury GM, McCleary WR: Genetic evidence suggests that the intergenic region between pst $A$ and $p s t B$ plays a role in the regulation of rpoS translation during phosphate limitation. J of Bacteriol 2007, 189(3):1150-1153

51. Castanie-Cornet MP, Penfound TA, Smith D, Elliott JF, Foster JW: Control of acid resistance in Escherichia coli. J of Bacteriol 1999, 181(11):3525-3535.

52. De Biase D, Tramonti A, Bossa F, Visca : The response to stationary-phase stress conditions in Escherichia coli: role and regulation of the glutamic acid decarboxylase system. Molecular Microbiol 1999, 32(6):1198-1211.

53. Unden $\mathrm{G}$, Achebach $\mathrm{S}$, Holighaus $\mathrm{G}$, Tran H-Q, Wackwitz B, Zeuner Y: Control of FNR function of Escherichia coli by $\mathrm{O}_{2}$ and reducing conditions. J Mol Microbiol Biotechnol 2002, 4(3):263-268.

54. Reinhart F, Achebach S, Koch T, Unden G: Reduced apo-fumarate nitrate reductase regulator (Apo FNR) as the major form of FNR in aerobically growing Escherichia coli. J of Bacteriol 2008, 190(3):879-886.

55. Warnecke T, Gill RT: Organic acid toxicity, tolerance, and production in Escherichia coli biorefining applications. Microbial Cell Factories 2005, 4:25.

56. Suziedeliene E, Suziede lis K, Garbenciute V, Normak S: The acid-inducible asr gene in Escherichia coli: transcriptional control by the phoBR operon. J Bacteriol 1999, 181(7):2084-2093.

57. Gajiwala KS, Burley SK: HdeA, a periplasmic protein that supports acid resistance in pathogenic enteric bacteria. J Mol Biol 2000, 295:605-612.

58. Tucker DL, Tucker N, Conway T: Gene expression profiling of the $\mathrm{pH}$ response in Escherichia coli. J Bacteriol 2002, 184(23):6551-6558.

59. Šeputienè V, MotiejŨnas D, Suzžiedeèlis K, Tomenius H, Normark S, Melefors $\mathrm{O}$, Sužiedèlienè E: Molecular characterization of the acidinducible asr gene of Escherichia coli and its role in acid stress response. J Bacteriol 2003, 185:2475-2484.

60. Šeputienè V, Sužiedèlis K, Normark S, Melefors $O$, Sužiedèlienè E: Transcriptional analysis of the acid-inducible asr gene in enterobacteria. Res in Microbiol 2004, 155:535-542.

61. Šeputienè V, Daugelavičius A, Suzžiedèlis K, Sužiedèliene E: Acid response of exponentially growing Escherichia coli K-12. Microbiol Res 2006, 161:65-74

62. Wanner BL, Wilmes MR, Young DC: Control of bacterial alkaline phosphatase synthesis and variation in an Escherichia coli K-12 phoR mutant by adenyl cyclase, the cyclic AMP receptor protein, and the phoM operon. J of Bacteriol 1988, 170(3):1092-1102.

63. Ninfa AJ, Jiang P, Atkinson MR, Peliska JA: Integration of antagonistic signals in the regulation of nitrogen assimilation in Escherichia coli. Curr Top Cell Regul 2000, 36:31-75.

64. Pratt LA, Silhavy TJ: The response regulator SprE controls the stability of RpoS. PNAS USA 1996, 93:2488-2492.

65. Ballesteros M, Fredriksson A, Henriksson J, Nystrom T: Bacterial senescence: protein oxidation in non-proliferating cells is dictated by the accuracy of the ribosomes. EMBO J 2001, 20(18):5280-5289.

66. Peterson CN, Mandel MJ, Silhavy TJ: Escherichia coli starvation diets: essential nutrients weigh in distinctly. J of Bacteriol 2006, 187(22):7549-7553

67. Groat RG, Schultz JE, Zychlinsky E, Bockman A, Matin A: Starvation proteins in Escherichia coli: kinetics of synthesis and role in starvation survival. J Bacteriol 1986, 168:486-493.

68. Matin A: The molecular basis of carbon-starvation-induced general resistance in Escherichia coli. Mol Microbiol 1991, 5:3-10.

69. Sultan SZ, Silva AJ, Benilez JA: The PhoB regulatory system modulates biofilm formation and stress response in El Tor biotype Vibrio cholerae. FEMS Microbiol Lett 2010, 302(1):22-31

70. Baba T, Ara T, Hasegawa M, Takai Y, Okumura Y, Baba M, Datsenko KA Tomita T, Wanner BL, Mori H: Construction of Escherichia coli K-12 inframe, single-gene knockout mutants: the Keio collection. Mol Syst Biol 2006, 2:2006.0008

71. Peng $L$, Shimizu K: Effect of fadR gene knockout on the metabolism of Escherichia coli based on analyses of protein expressions, enzyme activities and intracellular metabolite concentrations. Enzyme Microbiol Technol 2006, 38:512-520.

72. Sambrook J, Russel DW: Molecular Cloning: A Laboratory Manual. 3 edition. Cold Spring Horbor Laboratory Press, Cold Spring Harbor, NY; 2001

73. Kabir MM, Shimizu K: Gene expression patterns for metabolic pathway in pgi knockout Escherichia coli with and without phb genes based on RTPCR. J Biotechnol 2003, 105:11-31.
74. Kumar R, Shimizu K: Metabolic regulation of Escherichia coli and its gdhA, $g / n L, g l t B, D$ mutants under different carbon and nitrogen limitations in the continuous culture. Microbial Cell Factories 2010, 9:8.

doi:10.1186/1475-2859-10-39

Cite this article as: Marzan and Shimizu: Metabolic regulation of Escherichia coli and its $p h o B$ and $p h o R$ genes knockout mutants under phosphate and nitrogen limitations as well as at acidic condition. Microbial Cell Factories 2011 10:39.

\section{Submit your next manuscript to BioMed Central and take full advantage of:}

- Convenient online submission

- Thorough peer review

- No space constraints or color figure charges

- Immediate publication on acceptance

- Inclusion in PubMed, CAS, Scopus and Google Scholar

- Research which is freely available for redistribution

Submit your manuscript at www.biomedcentral.com/submit
C) Biomed Central 